\title{
Nuclear Waste Fund Fee Adequacy: An Assessment
}

\section{November 1990}

\section{U.S. Department of Energy}

Office of Civilian Radioactive Waste Management

Washington, DC 20585

\section{MASTER}




\section{DISCLAIMER}

This report was prepared as an account of work sponsored by an agency of the United States Government. Neither the United States Government nor any agency thereof, nor any of their employees, make any warranty, express or implied, or assumes any legal liability or responsibility for the accuracy, completeness, or usefulness of any information, apparatus, product, or process disclosed, or represents that its use would not infringe privately owned rights. Reference herein to any specific commercial product, process, or service by trade name, trademark, manufacturer, or otherwise does not necessarily constitute or imply its endorsement, recommendation, or favoring by the United States Government or any agency thereof. The views and opinions of authors expressed herein do not necessarily state or reflect those of the United States Government or any agency thereof. 


\section{DISCLAIMER}

Portions of this document may be illegible in electronic image products. Images are produced from the best available original document. 


\subsection{INTRODUCTION AND EXECUTIVE SUMMARY}

\section{Background}

The purpose of this report is to present the Department of Energy's (the Department) analysis of the adequacy of the 1.0 mill per kilowatt-hour $(\mathrm{kWh})$ fee being paid by the utilities generating nuclear power for the permanent disposal of their spent nuclear fuel (SNF). In accordance with the Nuclear Waste Policy Act ${ }^{l}$ (NWPA), the SNF would be disposed of in a geologic repository to be developed by the Department. An annual analysis of the fee's adequacy is required by the NWPA.

In December 1982, the Congress passed the NWPA which required the Department to proceed with a step-by-step process to select and characterize three candidate sites for the first permanent geologic repository for spent nuclear fuel and high-level waste. The NWPA also authorized the Department to select a site for a second repository. The NWPA directed that a fee of 1.0 mill per $\mathrm{kWh}$ of electricity generated and sold by a nuclear utility shall be collected into a fund (Nuclear Waste Fund) managed by the Department of Energy to pay the full costs of the program. In addition, the Department would pay its fair share of the costs to permanently dispose of the highlevel radioactive waste generated by its weapons production activities.

In 1985, President Reagan decided that separate facilities for utility spent fuel and Government generated wastes were not to be pursued, but that each party must pay its full respective share of the total program costs. A methodology for cost sharing was developed by public rulemaking ${ }^{2}$ and provided a vehicle for computing each party's fair share of total costs. Although the Department has committed to paying its full share, plus accrued interest, prior to waste acceptance at the repository, no monies have been paid to date. It should be clearly recognized that the non-receipt of Government monies at this time in no way changes the amount due and collectible from the nuclear utilities. This report addresses only the continuing adequacy of the 1.0 mill per $\mathrm{kWh}$ nuclear utility cost share.

In December 1987, Congress passed the Nuclear Waste Policy Amendments Act $^{3}$ (NWPAA) and directed the Department to stop all work on two of the candidate sites and to investigate only the Yucca Mountain, Nevada, site as a candidate for the first repository. The NWPAA also directed the Department to stop all work on the second repository program.

The siting of nuclear waste facilities has been a difficult process. Progress has been slower than anticipated because the program is a first-of-its-kind, and because the "not in my backyard" syndrome has been the position of virtually all potential host States. 
The program has been plagued by litigation at each step of the process. In 1987, the Department announced a delay in the schedule of the opening of the first repository from 1998 to 2003.

On November 29, 1989, the Secretary of Energy completed an extensive review of the Civilian Radioactive Waste Management Program and submitted to the Congress a report ${ }^{4}$ describing how the program would be restructured in order to get it moving forward again. The report announced the initiation of a three-point plan focusing on the restructuring of the Office of Civilian Radioactive Waste Management (OCRWM), initiatives to gain access to the Yucca Mountain candidate site to continue the scientific investigations needed to evaluate the site's suitability for a repository, and an initiative for establishing a Monitored Retrievable Storage (MRS) facility with a target for spent fuel acceptance in 1998. The reference program schedule contained in the Secretary's report, which announced a new repository opening date of 2010, has been formally baselined and program progress is being measured against it.

\section{Status of the Nuclear Waste Fund}

Through FY 1989, approximately $\$ 4.0$ billion has been paid by the utilities into the Nuclear Waste Fund (NWF). About $\$ 2.6$ billion of that is from the 1.0 mill per kWh fees and $\$ 1.4$ billion is from the one-time fees paid for spent fuel discharged prior to April 7, 1983. The fund has earned $\$ 609$ million in interest on investments in Government securities through FY 1989. As of the end of FY 1989, the NWF had a balance of $\$ 2.2$ billion. Interest paid at Treasury rates will continue to accumulate on investments. It is estimated that the NWF investments will earn about $\$ 195$ million in FY 1990.

It is fully expected that the NWF will at times exhibit a large positive balance, such as now when program expenses are low. Under the no-new-orders scenario of spent fuel projections, it is necessary for the fund balance to remain positive through the end of the program, since in this scenario there would be no new reactors expected to come on line that would provide additional revenues after the existing reactors are decommissioned. The fund balance is estimated to peak in the mid-2020's and decline steadily to zero at the end of the repository decommissioning about the year 2075 . 


\section{Program Status}

Through FY 1989, the program had spent $\$ 2.4$ billion. About $\$ 1.1$ billion was spent on the basalt and salt first repository candidate projects and the second repository program that were cancelled by the NWPAA. About $\$ 0.7$ billion has been spent on the Yucca Mountain Project. The remaining $\$ 0.6$ billion was spent on transportation, MRS, systems integration, technical support, engineering development, and program management.

Accomplishments at Yucca Mountain include 223 drillholes, 95 trenches and soil pits, 595 monitoring stations, 44 surveys of existing conditions, 8 underground tests, and numerous ongoing laboratory and modeling activities. Underground tests included geochemical and electromagnetic tests in G-Tunnel and geomechanical and thermal effects tests in the Climax Facility. Accomplishments in the MRS program include the siting proposal to Congress in $1987^{5}$ and the MRS systems studies ${ }^{6}$ prepared in support of the MRS Review Commission in 1988 and 1989. In the transportation program, contracts are underway for the design of new legal-weight truck casks and new rail/barge casks.

Program expenditures will continue through decommissioning and final closure of the repository, about 85 years into the future. With the exception of the collection of those remaining one-time fees that are due and payable when spent fuel is accepted for disposal by the Department, fees projected from the utilities will be paid in full when the final spent fuel assembly is discharged from the last reactor, now estimated to occur in about the year 2037, unless plant life is extended or new nuclear plants are ordered and constructed. When the exploratory shaft construction starts in 1992, the expenditures of the program will dramatically increase. Therefore, it is necessary to have sufficient fees collected in the early years to cover the anticipated high costs of scientific investigation and repository construction, and still have sufficient funds invested such that the fund balance and interest earned on the investments will be sufficient to pay the costs through the final closure of the repository, in approximately the 2075 timeframe.

\section{Factors Affecting the Adequacy of the Fee}

Congress anticipated the potential need at some time in the life of the program for changing the 1.0 mill per $\mathrm{kWh}$ fee and provided the method for recommending a change. The Department has recognized in previous fee adequacy reports that the fee will probably need to be increased at some time in the future. Several factors indicate this. First, since the 1.0 mill per $\mathrm{kWh}$ fee was established in the NWPA in 1982, the purchasing power of that fee has decreased annually with inflation. A recent General Accounting Office (GAO) report ${ }^{7}$ recommended that the Department use a realistic 
base-case inflation rate estimate to determine the adequacy of the 1.0 mill per $\mathrm{kWh}$ fee. In response to this recommendation, the Department has used a base-case inflation rate of 4 percent and a real interest rate of 3 percent in this analysis. Second, a Federal court decision requiring a change in the way that the 1.0 mill per $\mathrm{kWh}$ fee rate is calculated (to compensate for electricity transmission and distribution losses) will reduce the revenues received. Third, with the scenario of no new reactors being ordered, the estimated amount of fees to be received has been reduced significantly since the passage of the NWPA. Not only have the Energy Information Administration (EIA) upper reference case ${ }^{8}$ projections decreased over time due to the cancellation of nuclear plants already ordered and a reduction in the estimates of new plants to be ordered, but the Civilian Radioactive Waste Management Program has adopted the EIA no-new-orders case for planning purposes. Fourth, a recent report ${ }^{9}$ of the Office of the Inspector General (IG) concluded that the Department was at risk in not receiving the one-time fees owed to the NWF by the utilities who selected a deferred payment option under the "Standard Contract for Disposal of Spent Nuclear Fuel and/or High-Level Radioactive Waste, ${ }^{, 10}$ as modified ${ }^{11}$. Under the full cost recovery provisions of the NWPA, the failure of some utilities to pay their one-time fee payments could result in a refusal to accept their spent nuclear fuel or an increase in the kilowatt fees of the other utilities. The report recommended that the Department take the necessary actions to assure collection of those waste fees. The Department is discussing the options for resolving this matter with the IG, representatives of the utility industry, and the Nuclear Regulatory Commission. Fifth, the program schedule has been extended to 2010, coordination with the affected parties has been expanded; and the need for more information for the license application has been recognized; all these changes result in higher program cost estimates than previously estimated.

Details of the cost changes are documented in the published total system life cycle cost (TSLCC) reports supporting each fee adequacy analysis.

The recent GAO report mentioned above also recommended that the Department include estimates for additional scenarios, such as further program delays and a finding that Yucca Mountain would not be suitable for a repository. Further program delays and a finding of unsuitability of the Yucca Mountain candidate site are possible. Such scenarios would result in higher cost estimates and the fee being less adequate than indicated by the current analyses. However, the Department does not believe that these scenarios are sufficiently definable so as to be considered in the fee adequacy analysis at this time.

In the same report, the GAO reported a possible $\$ 2.4$ billion present value deficit in the NWF at the end of the program. This possible deficit was based upon revenue estimates and program assumptions that are no longer valid. Current revenue estimates and assumptions that are the basis of this analysis do not forecast a deficit in the Nuclear Waste Fund at the end of the program. 
There are several reasons why a fee increase at this time is not clearly indicated. First, inflation rates in the future are unknown, will have a significant impact on the fee adequacy calculation over a period of about 85 years, and therefore should be conservatively estimated in order to avoid overcollection of fees. Second, with a growing concern over the adequacy of electricity supply, energy security, alternatives to fossil fuels, and the possibility of global warming, a resurgence of nuclear power, and corresponding increased fund revenues, becomes increasingly possible. Also, there is a possibility that the operating life of existing reactors could be extended to 60 years, thereby creating more revenue from these reactors. Third, program costs vary by $\$ 8$ billion depending on whether a one-repository system or a two-repository system is assumed. Since the NWPAA directed the Department to stop all work on the second repository and wait about 20 years before determining the need for such a repository, it does not seem reasonable that a fee increase should be based on a two-repository system at this time. If later in the program there is a resurgence of the nuclear industry or if there are indications that the candidate first repository site may prove unfit or may not be capable of taking all of the projected waste, then this assumption could be revisited. In addition, with the recent announcement of a delay in the opening of the repository to the year 2010, many utilities are concerned about the additional cost of at-reactor storage during the delay years.

\section{Methodologies for Changing the Fee}

The Department's policy is to conduct a thorough analysis annually and to recommend a change in the fee when there is a compelling case for the change. Two methods have been considered by the Department for adjusting the fee when necessary. They are (1) indexing the fee to inflation, as discussed in previous fee adequacy reports, and (2) less frequent step adjustments.

The Department's preferred method for changing the fee is the step adjustment. This method provides for a change in the fee based upon programmatic as well as economic factors. It also requires the Department to fully justify each fee change proposed. If at any time the fee is found to be inadequate or more than adequate, an adjustment to the fee can be made such that the fund balance at the end of the program would be essentially zero. If the ending fund balance is positive (surplus), the fee may be decreased. If the fund balance is negative (deficit), the fee may be increased such that a near zero fund balance at the end of the program will be attained. 


\section{Findings and Conclusions}

Five fee adequacy reports ${ }^{12-16}$ have been published previously. The last one was dated June 1987. This report, the sixth, considers all program changes that have taken place since the last report was published. Based on an assessment contained in the remainder of this report of the variables discussed above, the Department does not recommend a change in the 1.0 mill per $\mathrm{kWh}$ fee.

This report contains the results of the analyses for a variety of scenarios involving construction of either one or two repositories; $2,3,4$, and 5 percent inflation rate projections; and 1, 2, 3, and 4 percent real interest rates. All scenarios included in the report are based on the assumption of the EIA no-new-orders spent fuel projections. Based on the findings in this analysis for a base-case scenario utilizing an inflation rate of 4 percent and a real interest rate of 3 percent, the Department does not find a compelling case for recommending a fee adjustment at this time. Analyses were also conducted using the EIA upper reference spent fuel projections to determine the impact on fee adequacy of a resurgence of the nuclear industry. The results, although not contained in this report, support the findings of this report. 


\subsection{METHODOLOGY AND ASSUMPTIONS}

\section{Methodology}

This evaluation of fee adequacy is based on the principle of "full cost recovery," under which the radioactive waste management program is to be reimbursed for all costs related to the waste disposal services it provides to the signatories of DOE's Standard Contract, as modified, as well as the cost for defense high-level waste (DHLW) disposal. The principle of full-cost recovery underlies the basic analytic approaches used by the Department in evaluating financing methods suited to a Federally administered program for the disposal of high-level nuclear waste.

The general methodology employed in this report projects NWF cash flows and resulting balances based on estimated program costs and revenues, including both interest earnings and interest expenses for borrowing. If the fund balance is projected to be near zero, then the fee is judged adequate to ensure full cost recovery. This analysis uses real interest rates of $1,2,3$, and 4 percent. To investigate the effects of a range of inflation, this year's analysis includes alternative inflation rates of $2,3,4$, and 5 percent. The final assessment of the adequacy of the fee is based on a base-case inflation and real interest rate combination. The base-case consists of a scenario of a single-repository system assuming 4 percent inflation and 3 percent real interest rates. In the last 5 years, the average inflation rate was 3.6 percent and in a recent study, ${ }^{17}$ the WEFA Group has forecasted that the average inflation rate for the next 20 years will be 4.4 percent. In the same study, the average annual real interest rate, based on Treasury securities was forecasted to be 3.1 percent. Since the NWF was created, the Treasury securities which the program invests in have earned, on average, 3 percent real interest on investments.

Under the NWPAA, only one repository is authorized, and only the Yucca Mountain, Nevada, candidate site is authorized for scientific investigations. This analysis assumes, for estimating purposes only, that the Yucca Mountain candidate site is found suitable for development as a repository and that the first repository is located at Yucca Mountain. If the Yucca Mountain site is found unsuitable for a repository, the waste management cost estimates would be recalculated to reflect the revised program. The NWPAA directed the Department to stop all work on the second repository and required the Department to report to Congress between 2007 and 2010 on the need for a second repository. As part of the sensitivity analysis, a two-repository system is also examined in this report. 


\section{Assumptions}

The principal assumptions underlying the analysis summarized in this report are listed below:

- Nuclear electric growth:

EIA "no-new-orders" projection

- Civilian spent fuel: cumulative discharge No-new-orders projection

86,800 metric tons of heavy metal (MTHM) through the year 2037

- Defense program wastes:

17,750 canisters, equivalent to 8,875 MTHM; assumed to be shipped from the defense facilities to the OCRWM repository(ies)

- System configuration and availability dates:

First Repository -2010

Second Repository -25 to 35 years after the decision on the (Two-Repository Case) need for a second repository has been made

Two-Phase Integrated

MRS facility --

Waste Acceptance with

Transport/Storage Capability --

1998

Full-Capability MRS --

2000

- Repository design capacity:

Single-Repository Case --

all wastes

Two-Repository Case --

70,000 metric tons of heavy metal (or its equivalent) for the first repository; the balance goes to the second repository

- Retrievability period: $\quad 50$ years after first emplacement

The ongoing fee revenue and spent-fuel projections used in this analysis were derived from the no-new-orders projection of net electricity generation and spent-fuel discharges ${ }^{18}$ prepared in 1988 by the EIA. In this projection, it was assumed that commercial nuclear units will operate for 40 years from the issuance of their operating licenses, reactor performance will not be affected by aging, and that the equilibrium-cycle capacity factor will increase gradually from 60 to 65 percent in 2000 then to 70 percent by 2020 . 
The assumption herein that there will be no new nuclear plant orders, that most reactors under active construction will be completed, and that the 40 year life of existing reactors will not be extended is for planning purposes at this time based on past circumstances. The assumption is not intended to be a projection of actual future nuclear plant orders or life extensions that may occur based on future circumstances. This assumption results in operable nuclear capacity that rises as plants now under construction are completed from 95 gigawatts (GW) in 1988 to $102 \mathrm{GW}$ in 1991 and $103 \mathrm{GW}$ in 1997, then declines after 2006 as plants are retired, to reach $51 \mathrm{GW}$ in 2020 and zero in 2037. In fact, there are growing concerns over the adequacy of electricity supply, energy security, alternatives to fossil fuels, and the possibility of global warming which have focused increased attention on the need for expanded use of nuclear power. This subject will be addressed in the National Energy Strategy (NES). The results of, and projections contained in, the NES will be reflected in the next report.

It should be noted that, since the NWF is projected to be in a surplus position for much of its life cycle, and since inflation also affects the nominal interest rate, the effects of inflation on outlays may be partially offset by higher nominal interest earnings.

This evaluation incorporates the December 1985 decision in Wisconsin Electric Power Co. v. Hodel, 778 F. 2d 1 (D.C. Cir. 1985) and the March 1989 decision in Consolidated Edison v. U.S. Department of Energy, 870 F. 2d 694 (D.C. Cir. 1989) that ongoing fees will be based on electricity generated and sold. At the end of FY 1989, the Department estimated that $\$ 0.2$ billion (exclusive of interest) would be credited or reimbursed to the utilities as a result of the revision of ongoing fees collected through FY 1990. For this analysis, the Department assumed a 7 percent reduction in net generation to account for electricity not sold.

Unless otherwise indicated, all dollar values in this report will be given in 1988 dollars in order to be consistent with the May 1989 TSLCC $^{19}$ report and the 1990 Addendum to that report. $^{20}$

\section{Significant Changes in Methodology and Assumptions}

The overall methods used for this analysis are the same as those used in the previous fee adequacy assessments. There are, however, a number of changes in major assumptions that are briefly summarized below. The initial acceptance of spent fuel at the MRS facility is assumed to begin in 1998 with a transport/storage system. A full capability MRS facility is then assumed to be operational in 2000 . The repository is assumed to begin operation in 2010. The second repository, in the cost case where it is considered, is assumed to begin operation about 25 to 35 years after a decision has 
been made on the need for a second repository. Cost estimates are based on a first repository in tuff at the Yucca Mountain, Nevada candidate site (the only site authorized under the law for scientific investigation) and a generic second repository medium.

Two additional changes from previous analyses should be noted. First, this analysis considers only cases with intact disposal of spent fuel. Previous analyses included consolidated disposal cases; however, since the reference waste form for the system is intact spent-fuel assemblies in disposal containers, consolidation is no longer considered in assessing the adequacy of the fee. If circumstances dictate (e.g., the estimates of waste package costs increase significantly over current estimates), the issue of consolidation may need to be revisited. Finally, previous analyses also considered a range of spent-fuel projections. This analysis is based on a single projection, no-neworders, because this projection provides a more conservative estimate of the fees paid into the NWF. An additional projection, the upper reference case projection, was examined to determine the implications of higher spent-fuel projections on the adequacy of the fee. The results of this case support the findings presented in this report but are not included as part of this analysis. 


\subsection{ANALYSIS}

This section discusses both revenue and program cost projections and describes the analysis used to assess the adequacy of the current 1.0 mill per $\mathrm{kWh}$ fee and one-time spent-fuel fee payments to fully recover the commercial (i.e., nondefense) program costs.

\section{$\underline{\text { Revenues }}$}

If the disposal fee remains unchanged at 1.0 mill per $\mathrm{kWh}$ of electricity generated and sold, the cumulative ongoing fee revenues are $\$ 19.0$ billion from FY 1983 to FY 2037 ( $\$ 16.5$ billion for FY 1990 through FY 2037) under the no-new-orders projection. The revenues from the ongoing fee for the disposal of spent nuclear fuel are distributed over time in proportion to annual net electrical generation. A total of approximately $\$ 4.0$ billion (current year dollars) in fees has been collected through FY 1989. At the end of FY 1989, the program had a fund balance with a market value of approximately $\$ 2.2$ billion. The OCRWM contract holders, primarily utilities, originally owed about $\$ 2.3$ billion in one-time fees to the NWF for disposal of the waste generated prior to April 7, 1983. At the end of June 1985, one-time fees totaling $\$ 1.4$ billion were paid. The balance of one-time fees, plus accrued interest from April 7, 1983, will be paid to the NWF either in quarterly installments or as a single lump-sum payment prior to the transfer of SNF to the Federal Government. In 1985, 3 utilities elected to pay $\$ 173$ million plus accrued interest by the 40 quarterly payment option, and 11 utilities elected to pay $\$ 735$ million plus accrued interest in the form of lump-sum payments prior to first delivery of SNF. As of the end of FY 1989, $\$ 23$ million in principal and interest have been paid on the 40 quarterly payment option. Through FY 1990, there have been no Congressional appropriations for DHLW disposal fees.

\section{Life-Cycle Costs}

Estimated total system life-cycle costs are organized into five major categories: (1) development and evaluation costs; (2) waste transportation costs; (3) geologic repository construction, operations, and decommissioning costs; (4) MRS costs; and (5) benefits payments to states and/or Indian tribes. Table 1 displays the total system life-cycle cost estimates for no-new-orders generation forecasts with one and two repositories. The cost estimates used are the updated cost cases based on a singlerepository and a two-repository system with a "basic MRS" facility from the May 1989 TSLCC. These estimates have been updated to reflect the restructured program presented in the Secretary's Report to Congress on Reassessment of the Civilian Radioactive Waste Management Program (DOE/RW-0247, November 1989). 
Table 1. Summary of Total System Life-Cycle Cost Components from 1983 through Decommissioning

(Billions of 1988 dollars)

\begin{tabular}{cccccccc}
\hline \multirow{2}{*}{$\begin{array}{c}\text { Number of } \\
\text { Repositories }\end{array}$} & D\&E & $\begin{array}{c}\text { Transpor- } \\
\text { tation }\end{array}$ & $\begin{array}{c}\text { Repository } \\
\text { First }\end{array}$ & Second & MRS $^{\mathbf{b}}$ & Benefits & Total $^{\mathbf{c}}$ \\
\hline One & 11.5 & 2.8 & 8.7 & NA & 1.9 & 0.7 & 25.6 \\
Two & 15.0 & 2.7 & 7.0 & 6.6 & 1.6 & 0.8 & 33.6 \\
\hline
\end{tabular}

a Development and Evaluation.

b Monitored Retrievable Storage.

c Rows may not add to totals because of independent rounding.

Appendix A contains a summary of the updated estimates. The total system costs are estimated to range from $\$ 25.6$ billion for the one-repository system to $\$ 33.6$ billion for the two-repository system. Life-cycle costs associated with development and evaluation (D\&E) cover the program administration costs and all the siting, testing, design development, regulatory, and institutional activities relating to one or two geologic repositories, an MRS facility, and the required transportation network. These costs are either $\$ 11.5$ billion or $\$ 15.0$ billion, depending on the number of repositories.

Life-cycle transportation costs reflect the use of transportation casks that will accept SNF that has a minimum cooling age of 5 years and technology and procedures to ship SNF from individual commercial reactor storage sites to the MRS facility or repository(ies). In addition, DHLW will be shipped from defense high-level waste sites directly to the repository(ies). For the cases examined, these costs range from $\$ 2.7$ billion to $\$ 2.8$ billion.

The total life-cycle repository cost estimate for a one-repository system is $\$ 8.7$ billion. For a two-repository system, the total life-cycle repository cost is $\$ 13.6$ billion.

MRS costs were estimated to be in the range of $\$ 1.6$ to $\$ 1.9$ billion. The costs vary between a single- and two-repository system because of the time the MRS facility is in operation. In the two-repository system, the MRS facility is assumed to service only the first repository.

Benefit payments are estimated to range from $\$ 0.7$ billion to $\$ 0.8$ billion. 
The total system cost results are alternatively stated in Table 2 for the entire life of the program (i.e., from 1983 through decommissioning of the repository) and from 1990 through decommissioning. Also shown in Table 2 are the civilian and defense shares of the total system cost. The defense waste share of the total system cost varies from $\$ 3.8$ to $\$ 5.8$ billion or 15 to 17 percent of total system costs over the life of the program.

Table 2. Summary of Total System Life-Cycle Costs -- Civilian and Defense Components for the Life of the Program and for 1990 Through Decommissioning

(Billions of 1988 dollars)

\begin{tabular}{|c|c|c|c|c|c|c|c|}
\hline \multirow{2}{*}{$\begin{array}{r}\text { Number of } \\
\text { Repositories }\end{array}$} & \multicolumn{2}{|c|}{$\begin{array}{c}\text { Civilian Waste Share } \\
\text { Onward from }\end{array}$} & \multicolumn{2}{|c|}{$\begin{array}{l}\text { Defense Waste Share } \\
\text { Onward from }\end{array}$} & \multicolumn{2}{|c|}{$\begin{array}{l}\text { Total Costs } \\
\text { Onward from }\end{array}$} & \multirow{2}{*}{$\begin{array}{l}\text { Defense Waste } \\
\text { Share } \\
\text { (Percent) }\end{array}$} \\
\hline & $1983^{a}$ & $1990^{a}$ & 1983 & 1990 & 1983 & 1990 & \\
\hline One & 21.8 & 19.7 & 3.8 & 3.4 & 25.6 & 23.1 & 14.9 \\
\hline Two & 27.9 & 25.8 & 5.8 & 5.3 & 33.6 & 31.1 & 17.3 \\
\hline
\end{tabular}

Rows may not add to totals because of independent rounding.

\section{Nuclear Waste Program Cash Flow Analysis}

The cost and revenue forecasts discussed above were combined in a series of cash flow analyses that simulate the financial status of the nuclear waste program over time. This simulation was based on guidelines for fund management set forth in the NWPA. These guidelines state that surpluses will be invested in Treasury securities or used to redeem outstanding debt, and that shortfalls in revenue will be met by redeeming securities held by the NWF or by borrowing from the U.S. Treasury, if necessary. The fee adequacy evaluation includes three major steps: (1) the estimation of total radioactive waste management program costs, (2) the allocation of these costs between civilian and defense high-level waste, and (3) the evaluation of the adequacy of civilian and defense waste disposal fees to cover their respective shares of costs. It is the premise of this analysis that fees paid for the disposal of DHLW will be sufficient, when taking account of interest paid to the NWF by the DOE and earnings on those funds by the NWF, to cover the full cost share for DHLW disposal.

This report focuses on the adequacy of the civilian fees to cover the estimated civilian share of program costs. 
Fee Adequacy. Table 3 presents the projected fund balance at the end of the program if the 1.0 mill per kwh fee remains unchanged for the life of the program. A variety of cases were analyzed for bounding purposes. A positive balance indicates a projected fund surplus and a negative balance indicates a projected deficit. Because of the long time period of the program (about 85 years into the future), the end fund balance is very sensitive to changes in program costs, inflation, and real interest rates. Therefore, the magnitude of the end fund balance must be evaluated in context. As indicated previously, the Department had identified a base-case consisting of a single repository, 4 percent inflation and 3 percent real interest rates. Table 3 indicates that this case has a projected end of the program fund balance of a positive $\$ 3$ billion. As indicated in the table, a slight decrease in the base-case real interest rate or a slight increase in the inflation rate would result in a zero end fund balance. Although not indicated in this table a change in the annual cost estimates of only 2 percent would also result in a zero fund balance at the end of the program. Based on this analysis, the Department does not find a compelling case for recommending a fee adjustment at this time.

Table 3. Projected End-of-Program Nuclear Waste Fund Balance, Civilian Portion, with Ongoing Fee Constant at $1.0 \mathrm{mill} / \mathrm{kWh}$

(Billions of 1988 dollars)

\begin{tabular}{ccccc}
\hline & \multicolumn{4}{c}{ Annual Rate of Inflation (Percent) } \\
$\begin{array}{c}\text { Percent Real } \\
\text { Interest }\end{array}$ & $2 \%$ & $3 \%$ & $4 \%$ & $5 \%$ \\
\hline Single Repository & & & & \\
$1 \%$ & -3 & -6 & -8 & -10 \\
$2 \%$ & 4 & -2 & -7 & -11 \\
$3 \%$ & 23 & 12 & 3 & -5 \\
$4 \%$ & 74 & 52 & 34 & \\
& & & & \\
Two Repository & & & -22 \\
$1 \%$ & -13 & -17 & -20 & -32 \\
$2 \%$ & -11 & -20 & -23 & -4 \\
\hline$\%$ & 13 & -7 & 28 & \\
$4 \%$ & 111 & 65 & & \\
\hline
\end{tabular}




\section{REFERENCES}

1. Nuclear Waste Policy Act of 1982, Pub. L. No. 97-425, January 7, 1983.

2. U.S. Department of Energy, Office of Civilian Radioactive Waste Management, "Civilian Radioactive Waste Management; Calculating Nuclear Waste Fund Disposal Fees for Department of Energy Defense Program Waste," pp. 31508-31524, Federal Register, Vol. 52 No. 161, August 20, 1987.

3. Nuclear Waste Policy Amendments Act of 1987, Pub. L. No. 100-203, December, 1987.

4. U.S. Department of Energy, Office of Civilian Radioactive Waste Management, Report to Congress on Reassessment of the Civilian Radioactive Waste Management Program (DOE/RW-0247), November 1989.

5. U.S. Department of Energy, Office of Civilian Radioactive Waste Management, Monitored Retrievable Storage Submission to Congress (DOE/RW-0035-1-Rev 1), Washington, D.C., March 1987.

6. U.S. Department of Energy, Office of Civilian Radioactive Waste Management, MRS System Study Summary Report (DOE/RW-0235), June 1989.

7. U.S. General Accounting Office, Nuclear Waste: Changes Needed in DOE User Fee Assessments to Avoid Funding Shortfall, GAO/RCED-90-65, June 1990.

8. U.S. Department of Energy, Energy Information Administration, Commercial Nuclear Power 1988: Prospects for the United States and the World (DOE/EIA-0438(88)), September 1988.

9. U.S. Department of Energy, Office of the Inspector General, Follow-up Review of Fees Paid by Civilian Power Industry to the Nuclear Waste Fund (DOE/IG-0280), March 26, 1990.

10. U.S. Department of Energy, "10 CFR Part 961, Standard Contract for Disposal of Spent Nuclear Fuel and/or High-Level Radioactive Waste," Federal Register, April 18, 1983. 
12. U.S. Department of Energy, Report on Financing the Disposal of Commercial Spent Fuel and Processed High-Level Radioactive Waste (DOE/S-0020-1), July 1983.

13. U.S. Department of Energy, Nuclear Waste Fund Fee Adequacy: An Assessment, July 1984.

14. U.S. Department of Energy, Nuclear Waste Fund Fee Adequacy: An Assessment (DOE/RW-0020), February 1985.

15. U.S. Department of Energy, Nuclear Waste Fund Fee Adequacy: An Assessment (DOE/RW-0020), March 1986.

16. U.S. Department of Energy, Nuclear Waste Fund Fee Adequacy: An Assessment (DOE/RW-0020), June 1987.

17. The WEFA Group, U.S. Long-Term Economic Outlook, Fourth Quarter, 1989, WEFA Inc., 1989.

18. U.S. Department of Energy, Energy Information Administration, World Nuclear Fuel Cycle Requirements 1988 (DOE/EIA-0436(88)), September 1988.

19. U.S. Department of Energy, Analysis of the Total System Life Cycle Cost for the Civilian Radioactive Waste Management Program (DOE/RW-0236), Washington, D.C., May 1989.

20. U.S. Department of Energy, Preliminary Estimates of the Total System Cost for the Restructured Program: An Addendum to the May 1989 Analysis of the Total System Life Cycle Cost for the Civilian Radioactive Waste Management Program (to be published). 
Appendix A

Addendum to the Analysis of the Total

System Life Cycle Cost for the Civilian

Radioactive Waste Management Program 


\subsection{INTRODUCTION}

In May of 1989, the Department of Energy (DOE) published the Analysis of the Total System Life Cycle Cost for the Civilian Radioactive Waste Management Program ${ }^{I}$ (the TSLCC analysis). The primary use of the TSLCC analysis is to help determine if fees paid by the waste generators will be sufficient to fully cover the cost of the OCRWM program (fee adequacy). Following this, in November of 1989, the Secretary of the DOE announced in the Report to Congress on Reassessment of the Civilian Radioactive Waste Management Program ${ }^{2}$ the restructuring of the OCRWM program. Included in the Secretary's Report is the "Revised Schedule for the Restructured Program." The major changes in the OCRWM program presented in this schedule include:

- Delaying the start of operations at the repository until the year 2010.

- $\quad$ Beginning limited waste acceptance at the MRS facility in the year 1998 via a transport/storage system.

- Beginning design waste acceptance at the MRS facility in the year 2000 .

This appendix provides updated estimates for two of the cases contained in the May 1989 TSLCC analysis which reflect the above changes. The two updated cases are not intended to be substituted for cases in the May 1989 TSLCC analysis. Rather, these estimates are an addendum to the May 1989 analysis and, as such, are referred to as the 1990 addendum to the May 1989 TSLCC analysis. The costs presented in this appendix are expressed in constant 1988 dollars in order to remain consistent with the May 1989 results which were developed on the basis of 1988 dollars.

Both cases examined in this appendix are based on the "no-new-orders, end-of-reactorlife" spent-fuel projection and on intact spent-fuel disposal. The first case presented is based on a single-repository system, and the second case is based on a two-repository system. The results of the updated analysis are presented in Table A-1 along with a comparison to the corresponding estimates from the May 1989 TSLCC report.

Based on the revised schedule for the program presented in the Secretary's Report, the total-system cost is estimated to be $\$ 25.6$ billion (in constant 1988 dollars) for the single-repository system and $\$ 33.6$ billion for the two-repository system. This represents increases of $\$ 1.7$ billion and $\$ 2.4$ billion, respectively, from the comparable cases in the May 1989 TSLCC (also expressed in constant 1988 dollars). These estimates represent a preliminary analysis of the impacts of the restructured program. A more definitive and comprehensive analysis of these impacts will be contained in the next report on the TSLCC analysis. 
Table A-1

Changes in TSLCC Estimates from the May 1989 TSLCC Analysis ${ }^{a}$

(Billions of 1988 dollars)

\begin{tabular}{|c|c|c|c|c|c|c|}
\hline \multirow[t]{2}{*}{ Component } & \multicolumn{3}{|c|}{$\begin{array}{l}\text { Single-repository } \\
\text { System }\end{array}$} & \multicolumn{2}{|c|}{$\begin{array}{l}\text { Two-repository } \\
\text { System }\end{array}$} & \multirow[b]{2}{*}{ Change $^{b}$} \\
\hline & $\begin{array}{l}\text { May } \\
1989\end{array}$ & 1990 & Change $^{b}$ & $\begin{array}{l}\text { May } \\
1989\end{array}$ & 1990 & \\
\hline$D \& E$ & 9.7 & 11.5 & 1.9 & 13.1 & 15.0 & 2.0 \\
\hline MRS $^{c}$ & 1.8 & 1.9 & 0.1 & 1.4 & 1.6 & 0.2 \\
\hline Transportation & 2.6 & 2.8 & 0.2 & 2.3 & 2.7 & 0.3 \\
\hline First repository & 9.1 & 8.7 & -0.3 & 7.0 & 7.0 & 0.0 \\
\hline Second repository & NA & NA & NA & 6.6 & 6.6 & 0.0 \\
\hline Benefits payments & 0.7 & 0.7 & 0.0 & 0.9 & 0.8 & -0.1 \\
\hline Total $^{d}$ & 23.8 & 25.6 & 1.7 & 31.2 & 33.6 & 2.4 \\
\hline
\end{tabular}

\footnotetext{
a Both cases assume the no-new-orders, end-of-reactor-life spent fuel projection and intact spent fuel disposal. May 1989 results subtracted from the 1990 updated results.

Basic MRS facility.

Columns may not add to totals because of independent rounding.
}

The cost estimating methodology, engineering assumptions, and cost data used in this analysis are generally the same as those utilized in the May 1989 analysis. Additional assumptions concerning the transport/storage system utilized at the MRS facility in 1998 and 1999 were included as appropriate. The following sections discuss the changes in methodology, assumptions, logistics, and data and also compare the updated estimates to the May 1989 estimates for each of the TSLCC components (development and evaluation, transportation, repository, MRS, and benefits payments).

\subsection{WASTE LOGISTICS}

The waste logistics were changed for the single- and two-repository systems to reflect the revised MRS facility and repository start dates presented in the Secretary's Report. The MRS facility was assumed to begin limited waste acceptance in 1998 via the transport/storage system and design waste acceptance in 2000 . The first repository start date for both the single- and two-repository systems was changed to 2010. In the tworepository system case, the second repository start date was assumed to also be delayed an equivalent number of years as was the first repository. Most of the cost impacts from the May 1989 analysis are due to changes in the waste logistics resulting from the restructured program schedule. 


\subsection{DEVELOPMENT AND EVALUATION COSTS}

The D\&E costs for the single-repository system increased from $\$ 9.7$ billion in the May 1989 TSLCC analysis to $\$ 11.5$ billion. The D\&E costs for the two-repository system increased from $\$ 13.1$ billion to $\$ 15.0$ billion for the respective TSLCC analyses.

The D\&E costs for the 1990 TSLCC addendum for fiscal years FY 1983 through FY 1989 were based on actual costs as reported by DOE's Financial Information System. The primary source of data for the costs of program activities starting in FY 1990 and extending through FY 1995 was the information developed for the FY 1991 budget request submitted to Congress in January 1990. The D\&E cost estimates in the May 1989 analysis were based on the budget information contained in the FY 1990 budget request submitted to Congress in January 1989.

The most significant increase in the D\&E costs is in the first-repository D\&E category. D\&E costs for this category increased by $\$ 1.2$ billion over the May 1989 TSLCC estimates. Most of this increase is due to the additional years of site characterization for the tuff repository project as a result of the new schedule. The remaining D\&E categories also contributed to the increases in the updated 1990 TSLCC estimates. However, these increases were less significant than the first-repository D\&E cost increases. Table A-2 shows the changes for each D\&E category for the two cost cases.

\subsection{TRANSPORTATION COSTS}

The transportation costs for the single-repository system increased from $\$ 2.6$ billion in the May 1989 TSLCC to $\$ 2.8$ billion in the 1990 TSLCC addendum. The transportation costs for the two-repository system increased from $\$ 2.3$ billion to $\$ 2.7$ billion. The majority of the cost increase in both cases (approximately $\$ 0.2$ billion) is due to the costs associated with a conservative estimate of a transport/storage system that could be utilized in the first two years of acceptance at the MRS facility. For the two-repository system, the additional increase in cost is due to an extended operating life for the cask maintenance facility which is assumed to service the MRS facility and both repositories. The cask maintenance facility is assumed to begin operating the same year as the MRS facility and continue operating until the end of operations at the second repository. With the assumed delay in the second repository start date, the cask maintenance facility must now operate an additional number of years equivalent to the delay. 
Table A-2

Increases in D\&E Costs from the May 1989 TSLCC Analysis

(Billions of 1988 dollars)

\begin{tabular}{lcc}
\hline Component & $\begin{array}{c}\text { Single-repository } \\
\text { System }\end{array}$ & $\begin{array}{c}\text { Two-repository } \\
\text { System }\end{array}$ \\
\hline First repository & & 1.2 \\
Second repository & 1.2 & 0.0 \\
MRS & 0.0 & 0.0 \\
Transportation & 0.0 & 0.2 \\
Systems integration & 0.2 & 0.1 \\
NRC fees & 0.1 & 0.1 \\
Government administration & 0.1 & 0.3 \\
& 0.2 & - \\
Total D\&E cost increase & - & 2.0 \\
\end{tabular}

a Columns may not add to totals because of independent rounding.

\subsection{REPOSITORY COSTS}

The repository costs for the single-repository system decreased from $\$ 9.1$ billion in the May 1989 TSLCC to $\$ 8.7$ billion. The majority of this cost reduction ( $\$ 0.3$ billion) is due to a shorter emplacement period required as a result of the delay in the repository start date to 2010. This shorter emplacement period results from the fact that, in the single-repository system, the repository must accept and emplace spent fuel through the year 2042, since the last discharge is in 2037. Thus, by delaying the repository until 2010 , the required emplacement period is reduced by 7 years. An additional reduction in costs is realized due to the emplacement of older, and thus, colder spent fuel resulting in a reduction in the total excavation requirements.

For the two-repository system, there was no significant reduction in the first repository costs from the May 1989 TSLCC estimate of $\$ 7.0$ billion. The second repository costs decreased from $\$ 6.6$ billion in the May 1989 TSLCC to $\$ 6.5$ billion due primarily to a shorter emplacement period resulting from the delay in the second repository start date.

\subsection{COSTS FOR AN MRS FACILITY}

The MRS facility costs for the single-repository system increased from $\$ 1.8$ billion in 
the May 1989 TSLCC to $\$ 1.9$ billion. This increase in costs of $\$ 0.1$ billion is due to the additional costs at the MRS facility for implementing the transport/storage system in the first two years of operation. The DOE is evaluating alternative concepts for the MRS facility. The concept estimated represents a conservative cost estimate for fee adequacy analysis. The MRS facility costs for the two-repository system increased from $\$ 1.4$ billion to $\$ 1.6$ billion. This cost increase of $\$ 0.2$ billion is due to both the additional costs associated with the transport/storage system and the costs of 7 additional years of operation required as a result of delaying the first repository start date from 2003 to 2010 . The costs incurred for operating the MRS facility over a longer period of time were somewhat offset by a reduction in costs associated with a reduced throughput rate required prior to repository operations in order to maintain the total MRS inventory below the current statutory limits, (i.e., 10,000 MTHM prior to repository operations and 15,000 MTHM thereafter).

\subsection{BENEFITS PAYMENTS}

The benefits payments costs decreased only slightly for the single-repository system (less than $\$ 0.1$ billion) and the two-repository system (approximately $\$ 0.1$ billion) resulting in the total benefits payments costs of $\$ 0.7$ billion and $\$ 0.8$ billion for these cases, respectively. These cost decreases can be attributed to the delay in the repository start dates from those assumed in the May 1989 analysis.

\subsection{COSTS FOR THE DISPOSAL OF DEFENSE WASTE}

The defense costs for both the single- and two-repository systems increased between the May 1989 TSLCC and these 1990 addendum cases. The defense cost of the singlerepository system increased from $\$ 3.6$ billion to $\$ 3.8$ billion. In the two-repository system, the defense costs increased from $\$ 5.4$ billion to $\$ 5.8$ billion.

The primary source of the increase in costs for the single-repository system was due to an increase in D\&E ( $\$ 0.3$ billion) costs due to the delay in the start of repository operations to 2010 . This increase was partially offset by small decreases in benefits payments and repository costs due to the seven year decrease in emplacement operations. The defense costs for the two-repository system increased by $\$ 0.4$ billion due primarily to increases in D\&E costs ( $\$ 0.3$ billion) and second repository costs ( $\$ 0.1$ billion). Again, these cost increases were partially offset by decreases in benefits payments and first repository costs. Table A-3 presents the defense-waste share of the total-system costs for the updated cases along with a comparison to the May 1989 TSLCC results for both the single- and two-repository cases. 
Table A-3

Defense Share of the Total-System Costs ${ }^{\mathrm{a}}$. (Billions of 1988 dollars)

\begin{tabular}{|c|c|c|c|c|c|c|}
\hline \multirow[t]{2}{*}{ Component } & \multirow[b]{2}{*}{$\begin{array}{l}\text { May } \\
1989\end{array}$} & \multicolumn{2}{|c|}{$\begin{array}{l}\text { Single-repository } \\
\text { System }\end{array}$} & \multicolumn{2}{|c|}{$\begin{array}{l}\text { Two-repository } \\
\text { System }\end{array}$} & \multirow[b]{2}{*}{ Change $^{b}$} \\
\hline & & 1990 & Change $^{b}$ & $\begin{array}{l}\text { May } \\
1989\end{array}$ & 1990 & \\
\hline $\begin{array}{l}\text { D \& E } \\
\text { Transportation } \\
\text { First repository } \\
\text { Second repository } \\
\text { Benefits payments }\end{array}$ & $\begin{array}{l}1.5 \\
0.3 \\
1.7 \\
\text { NA } \\
0.1\end{array}$ & $\begin{array}{l}1.8 \\
0.3 \\
1.6 \\
\text { NA } \\
0.1\end{array}$ & $\begin{array}{c}0.3 \\
0.0 \\
-0.1 \\
\text { NA } \\
0.0\end{array}$ & $\begin{array}{l}2.2 \\
0.4 \\
1.3 \\
1.3 \\
0.1\end{array}$ & $\begin{array}{l}2.6 \\
0.4 \\
1.3 \\
1.4 \\
0.1\end{array}$ & $\begin{array}{l}0.3 \\
0.0 \\
0.0 \\
0.1 \\
0.0\end{array}$ \\
\hline Total $^{c}$ & 3.6 & 3.8 & 0.2 & 5.4 & 5.8 & 0.4 \\
\hline
\end{tabular}

a Both cases assume the no-new-orders, end-of-reactor-life spent fuel projection and intact spent fuel disposal.

b May 1989 results subtracted from the 1990 updated results.

c Columns may not add to totals because of independent rounding. 


\subsection{REFERENCES}

1. U.S. Department of Energy, Office of Civilian Radioactive Waste Management, Analysis of the Total System Life Cycle Cost for the Civilian Radioactive Waste Management Program, DOE/RW-0236, Washington, D.C., May 1989.

2. U.S. Department of Energy, Office of Civilian Radioactive Waste Management, Report to Congress on Reassessment of the Civilian Radioactive Waste Management Program, DOE/RW-0247, Washington, D.C., November 1989. 